Provided for non-commercial research and education use. Not for reproduction, distribution or commercial use.

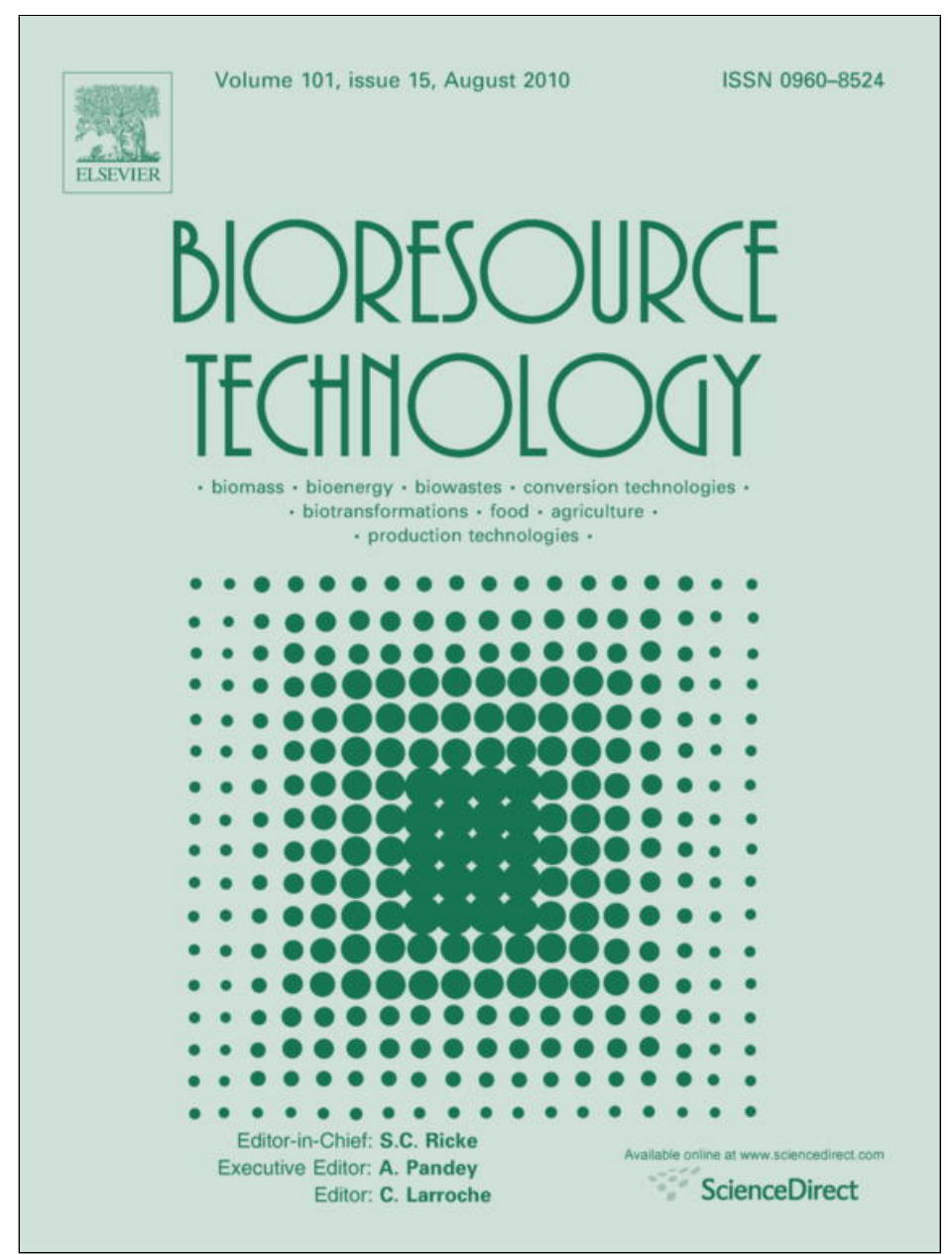

This article appeared in a journal published by Elsevier. The attached copy is furnished to the author for internal non-commercial research and education use, including for instruction at the authors institution and sharing with colleagues.

Other uses, including reproduction and distribution, or selling or licensing copies, or posting to personal, institutional or third party websites are prohibited.

In most cases authors are permitted to post their version of the article (e.g. in Word or Tex form) to their personal website or institutional repository. Authors requiring further information regarding Elsevier's archiving and manuscript policies are encouraged to visit:

http://www.elsevier.com/copyright 


\title{
Enzymatic saccharification of biologically pre-treated wheat straw with white-rot fungi
}

\author{
Albino A. Dias ${ }^{a}$, Gil S. Freitas ${ }^{a}$, Guilhermina S.M. Marques ${ }^{b}$, Ana Sampaio ${ }^{a}$, Irene S. Fraga ${ }^{\text {, }}$ \\ Miguel A.M. Rodrigues ${ }^{c}$, Dmitry V. Evtuguin ${ }^{\mathrm{d}}$, Rui M.F. Bezerra ${ }^{\mathrm{a}, *}$ \\ ${ }^{a}$ CITAB, Universidade de Trás-os-Montes e Alto Douro, Department of Biology and Environment, Apartado 1013, 5001-801 Vila Real, Portugal \\ ${ }^{\mathrm{b}}$ Universidade de Trás-os-Montes e Alto Douro, Department of Agronomy, Apartado 1013, 5001-801 Vila Real, Portugal

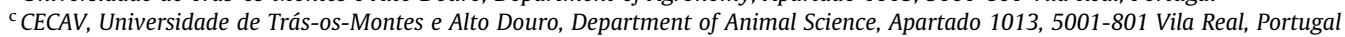 \\ ${ }^{\mathrm{d}}$ CICECO, Universidade de Aveiro, 3810-193 Aveiro, Portugal
}

\section{A R T I C L E I N F O}

\section{Article history:}

Received 11 January 2010

Received in revised form 24 February 2010

Accepted 25 February 2010

Available online 21 March 2010

\section{Keywords:}

White-rot fungi

Delignification

Cellulose accessibility

\begin{abstract}
A B S T R A C T
Wheat straw was submitted to a pre-treatment by the basidiomycetous fungi Euc-1 and Irpex lacteus, aiming to improve the accessibility of cellulose towards enzymatic hydrolysis via previous selective bio-delignification. This allowed the increase of substrate saccharification nearly four and three times while applying the basidiomycetes Euc-1 and I. lacteus, respectively. The cellulose/lignin ratio increased from 2.7 in the untreated wheat straw to 5.9 and 4.6 after the bio-treatment by the basidiomycetes Euc- 1 and I. lacteus, respectively, thus evidencing the highly selective lignin biodegradation. The enzymatic profile of both fungi upon bio-treatment of wheat straw have been assessed including laccase, manganese-dependent peroxidase, lignin peroxidase, carboxymethylcellulase, xylanase, avicelase and feruloyl esterase activities. The difference in efficiency and selectivity of delignification within the two fungi treatments was interpreted in terms of specific lignolytic enzyme profiles and moderate xylanase and cellulolytic activities.
\end{abstract}

(c) 2010 Elsevier Ltd. All rights reserved.

\section{Introduction}

Biomass has been recognized as one of the major world renewable energy source and cellulose is its major fraction. Cereal straws, one of the most abundant agricultural wastes, are a relatively slow decomposing substrate because it has high content of lignin and low content of nitrogen. Wheat straw is one of the major crop residues in European countries, with a production of $170 \times 10^{6}$ ton per year, and one of the cheapest and main useful raw materials for lignocellulose biotransformation (Tabka et al., 2006). The ability of several white-rot fungi species to selectively degrade the lignin component of wood has great potential for applications in industries processing lignocellulosic materials to produce cellulose, bio-fuels, or cellulose-enriched forage for ruminants. The main challenge in the biotechnology improvement of biomass is the pre-treatment step (Cardona and Sanchez, 2007).

After holocellulose, lignin is the most abundant biological compound found in nature. However, it is degraded by only a small number of microorganisms, primarily basidiomycetes (Hofrichter et al., 1999). Fungal growth on lignocellulosic substrates has been known for several centuries and has been used traditionally for producing edible mushrooms. Some fungal species have the ability to selectively delignify plant materials leaving a cellulose-enriched

\footnotetext{
* Corresponding author. Tel.: +351 259350 465; fax: +351 259350480 .

E-mail address: bezerra@utad.pt (R.M.F. Bezerra).
}

residue. White-rot fungi (WRF) produce lignin degrading enzymes that breakdown the lignin "seal" exposing the hemicellulose and cellulose in the wood matrix. Such characteristic could be useful in providing an unprotected carbohydrate for subsequent use, e.g., animal feed or bio-fuel substrate (Rodrigues et al., 2008). A mushroom producing plant coupled with a biorefinery could help generate both food and fuel ultimately benefiting the rural economy and offers the potential for the development of sustainable biomaterials that will lead to a new paradigm (Kalia and Purohit, 2008).

Lignin is chemically difficult to degrade because it is a threedimensional polymer interconnected through diverse carbon-carbon and other bonds that are not hydrolysable under biological conditions. Plant cell wall degrading enzymes have been classified into enzyme systems such as cellulolytic, ligninolytic and xylanolytic which reflect the nature of the polymers that these enzymes breakdown. The capability to degrade lignin presented by several WRF is due to their extracellular non-specific and non-stereoselective enzyme system (Levin et al., 2008) composed mainly by laccase, lignin peroxidase (LiP) and manganese-dependent peroxidase (MnP). Lignin peroxidases are strong oxidants that interact directly with non-phenolic lignin structures to cleave them, but cannot penetrate the small pores in sound lignocellulose. Manganese-dependent peroxidases produce small diffusible strong oxidants that can penetrate the substrate. Ferulic acid and $p$-coumaric acids that are esterified to hemicellulose sugars constitute another limitation to biodegradation of lignocellulosic walls and thus the feruloyl 
esterase is another key enzyme in the delignification process. Most of the feruloyl esterases have been shown to act synergistically with cellulases, xylanases and pectinases to break down complex plant cell wall carbohydrates (Hermoso et al., 2004).

The main goal of the present work was to investigate the potential of two white-rot fungal species and its enzymatic systems in the delignification of wheat straw. After fungal pre-treatment, the increase in cellulose accessibility towards cellulases was evaluated aiming to determine the susceptibility of the residual carbohydrates to enzymatic hydrolysis.

\section{Methods}

\subsection{Fungal strains}

Two basidiomycetous strains were used to obtain the enzymatic extracts, being isolate Euc-1, and Irpex lacteus. These WRF were isolated from decaying plant materials collected in North of Portugal and were previously characterized by Dias et al. (2003) and Gomes (2004) respectively. They were maintained on potato dextrose agar (PDA) plates at $4{ }^{\circ} \mathrm{C}$ and periodically subcultured.

\subsection{Enzyme production}

The fungi were grown on wheat straw solid media as described earlier (Dinis et al., 2009). Briefly, enzyme extracts were obtained from a solid culture medium containing $15 \mathrm{~g}$ of wheat straw with $0.05 \mathrm{~g}$ of glucose in $45 \mathrm{ml}$ of deionised water. Incubations took place in $250 \mathrm{ml}$ Erlenmeyer flasks containing the culture media and two $10 \mathrm{~mm}$ agar plugs removed from each isolated fungus. Flasks were incubated at $28{ }^{\circ} \mathrm{C}$ and fermented straw from four flasks of each fungus was harvested every 15 days until 46 days after inoculation. After harvesting, contents of the culture flasks were suspended in $150 \mathrm{ml}$ of deionized water and incubated on a rotary shaker $(100 \mathrm{rpm})$ for $3 \mathrm{~h}$. Extracts were filtered (Whatman $\mathrm{GF} / \mathrm{A}$ ), centrifuged and aliquots were used to determine enzyme activities (Dinis et al., 2009).

\subsection{Enzyme assays}

Enzyme activities were determined at $25{ }^{\circ} \mathrm{C}$ using a Helios gamma UV-vis spectrophotometer (Thermo Fischer Scientific). Ligninolytic activities were monitored as previously described (Dias et al., 2003) using $0.1-0.4 \mathrm{ml}$ of culture samples and the respective buffered substrate in $1.5 \mathrm{ml}$ total reaction volume. Briefly, manganese peroxidase activity was determined according to the modified method of Heinfling et al. (1998) by the formation of $\mathrm{Mn}^{3+}$-tartrate $\left(\varepsilon_{238}=6.5 \mathrm{mM}^{-1} \mathrm{~cm}^{-1}\right)$ from $0.10 \mathrm{mM} \mathrm{MnSO}_{4}$ using $100 \mathrm{mM}$ tartrate buffer ( $\mathrm{pH} \mathrm{5}$ ) and $0.10 \mathrm{mM} \mathrm{H}_{2} \mathrm{O}_{2}$. Lignin peroxidase activity was monitored at pH 3.0 according to Tien and Kirk (1988), and the formation of veratraldehyde was monitored at $310 \mathrm{~nm}$ $\left(\varepsilon_{310}=9.3 \mathrm{mM}^{-1} \mathrm{~cm}^{-1}\right)$. Laccase was measured following oxidation

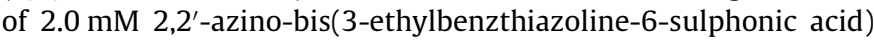
(ABTS) at $420 \mathrm{~nm}$ (Dias et al., 2004). Assay of feruloyl esterases was performed as reported by Mastihuba et al. (2002) through a spectrophotometric method by measuring the production of 4-nitrophenol (4NP) from 4-nitrophenyl ferulate, which was obtained from the Institute of Chemistry of the Slovak Academy of Sciences, Slovakia. After $30 \mathrm{~min}$ incubation at $50{ }^{\circ} \mathrm{C}$, $4 \mathrm{NP}$ released from $1 \mathrm{mM}$ substrate (final concentration) buffered with $100 \mathrm{mM}$ phosphate at $\mathrm{pH} 6.5$ was determined by absorbance readings at $410 \mathrm{~nm}$. Absorbance was converted into concentration through a standard curve prepared with $4 \mathrm{NP}(0.05-0.5 \mathrm{mM})$.

For cellulolytic enzyme assays, activities of carboxymethylcellulase (CMCase) and Avicell digesting cellulase (avicelase) were measured according to the IUPAC recommendations (Bezerra and Dias, 2004). The reducing sugars released were determined by the dinitrosalicylic acid (DNS), using glucose as a standard. Xylanase activity was determined under similar conditions for CMCase, except that $1 \%(\mathrm{w} / \mathrm{v})$ xylan solution was used as the substrate.

\subsection{Determination of cellulose accessibility after pre-treatment by WRF}

This assay was designed to evaluate the increase of cellulose accessibility to cellulases. For this purpose the accessibility of hydrolytic enzymes (Onozuka R-10, Merck) after pre-treatment by WRF was determined. The enzymes and activities present in this commercial mixture (Onozuka R-10) were: CMCase $\left(1 \mathrm{U} \mathrm{mg}^{-1}\right), \alpha$-amylase $\left(0.5 \mathrm{U} \mathrm{mg}^{-1}\right)$, endo-1,3- $\beta$-D-glucanase $\left(0.2 \mathrm{U} \mathrm{mg}^{-1}\right)$, xylanase $\left(10 \mathrm{U} \mathrm{mg}^{-1}\right), \beta$-glucosidase $\left(0.04 \mathrm{U} \mathrm{mg}^{-1}\right)$, protease $8 \mathrm{U} \mathrm{mg}^{-1}$, pectinase $0.1 \mathrm{U} \mathrm{mg}^{-1}$. Previously, pre-treated straw was washed, in order to remove the mycelium and soluble molecules. Dried straw was weighed $(0.06 \mathrm{~g})$ and the samples were placed in test tubes and then $10 \mathrm{ml}$ of $50 \mathrm{mM}$ citrate buffer $\mathrm{pH} 4.8$ with $0.01 \%$ sodium azide was added. After "swelling" overnight, $1 \mathrm{ml}$ of Onozuka R-10 with $2.5 \mathrm{U} \mathrm{ml}^{-1} \mathrm{CMCase}$ activity it was added. The tubes were incubated for $24 \mathrm{~h}, 45^{\circ} \mathrm{C}(100 \mathrm{rpm})$. The reducing sugars were determined by dinitrosalicylic method (Bezerra and Dias, 2004). Controls were submitted to the same procedures, except to fungal pre-treatment.

\subsection{Chemical analyses}

The lignin content in wheat straw before and after the bio-treatment was determined as acid-insoluble Klason lignin according to procedure adapted from TAPPI standard T222 om-88 (Browning, 1967). Typically ca. $1.0000 \mathrm{~g}$ of extractives/protein free sample with known ash content was hydrolysed during $2.5 \mathrm{~h}$ in $15 \mathrm{~mL}$ of $72 \% \mathrm{H}_{2} \mathrm{SO}_{4}$ at $25^{\circ} \mathrm{C}$ followed by dilution with $200 \mathrm{~mL}$ of distilled water and consecutive $1 \mathrm{~h}$ hydrolysis under reflux $\left(100^{\circ} \mathrm{C}\right)$. Acidinsoluble lignin was determined gravimetrically and its percentage corrected for the content of ash, extractives and protein in the original sample. The extractives were eliminated from analysed samples by Soxhlet-extraction with acetone $(4 \mathrm{~h})$, and proteins were eliminated by treatment with $1 \%$ pepsin solution at $\mathrm{pH} 2$ for $24 \mathrm{~h}$ $\left(40^{\circ} \mathrm{C}\right)$ using liquid/solid ratio 40 . The ash content was determined after sample calcination at $550{ }^{\circ} \mathrm{C}$ for $4 \mathrm{~h}$.

The cellulose content was assessed using the Kürschner and Hoffer method via extraction of lignin and hemicelluloses with ethanol $/ \mathrm{HNO}_{3}(4 / 1, \mathrm{v} / \mathrm{v})$ consecutively four times under reflux for $1 \mathrm{~h}$ (solution-to-wood ratio 50 ).

\subsection{Data processing and statistical analysis}

All experimental points are the average values of at least three independent experiments. The data were collected in a Microsoft Excel spreadsheet where the average and standard deviation were determined. One-way analysis of variance (one-way ANOVA) at a significance level of $5 \%$ was carried out with the software STATISTICA, version 9.0 to test the statistical significance of differences between the controls and fungal (Euc-1 or I. lacteus) pre-treated wheat straw. Thus, the null hypothesis was rejected when $P<0.05$.

\section{Results and discussion}

\subsection{Ligninolytic potential of fungal isolates}

The basidiomycetous fungi Euc-1, and I. lacteus, were pre-selected in previous work for the bio-treatment of wheat straw from a series of four WRF (Fomes fomentarius, Euc-1, I. lacteus, and 

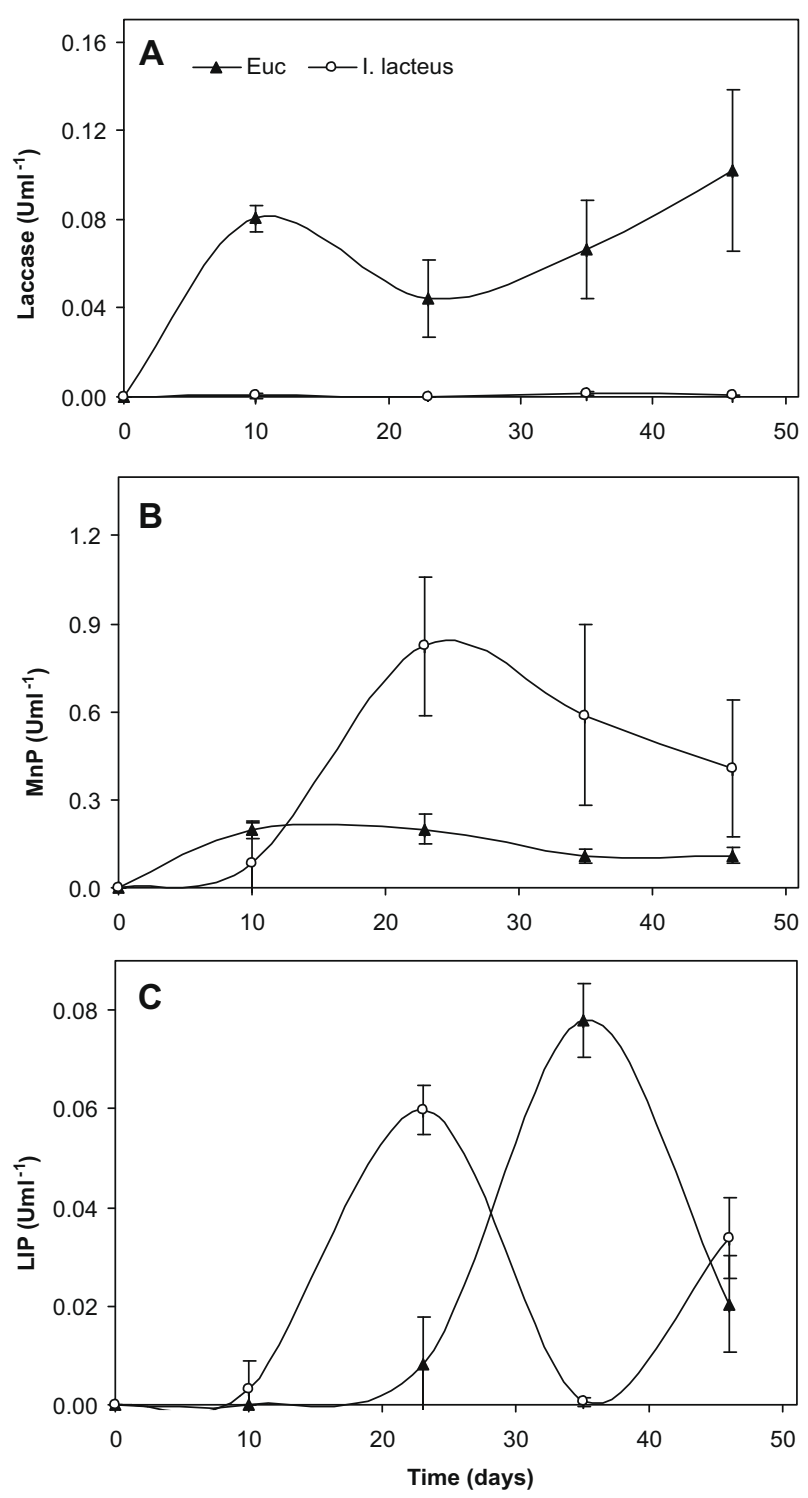

Fig. 1. Laccase (A), manganese-dependent peroxidase (B) and lignin peroxidase (C) activities measured during solid state incubation with wheat straw in the presence of two different fungi (I. lacteus and strain Euc-1).

Phanerochaete chrysosporium) following the criteria of highest efficiency and selectivity of the bio-delignification (Freitas, 2008). During the incubation period (46 days) laccase was only produced by basidiomycete Euc-1 (Fig. 1A). The isolated Euc-1 had a maximum production of laccase $\left(0.10 \mathrm{U} \mathrm{ml}^{-1}\right)$ at the end of incubation period. According to Zhang et al. (2008) the maximum laccase activities were detected during the first 10 days of wheat straw incubation with Trametes versicolor. However, with Euc-1 the same features were not observed.

In the case of I. lacteus, laccase activity was not detected though in other studies the presence of low activity of this enzyme in the presence of other carbon sources has been determined (Novotny et al., 2000). These differences could be interpreted as the result of different incubation periods and/or by the presence of different growth media composition (Dinis et al., 2009).

The manganese-dependent peroxidase activity was detected in solid state fermentation after 10 days with both fungi studied (Fig. 1B). It was observed a peak after 23 days of solid state fermentation with I. lacteus, showing a MnP activity about three times greater $\left(0.82 \mathrm{U} \mathrm{ml}^{-1}\right)$ than the activity determined with Euc-1 strain. The presence of MnP activity with I. lacteus is supported by experiments performed by other authors (Tanaka et al., 1999). The Euc-1 strain showed relatively low manganese peroxidase activity, and similarly to others studies performed with $P$. chrysosporium (Jaszek et al., 2006), demonstrated a decrease in this activity after 10 days of incubation. The results obtained revealed that $\mathrm{MnP}$ is the predominant ligninolytic enzyme secreted during solid state fermentation of wheat straw. This is in agreement with 10 times higher maximum levels of manganese peroxidase than the maximum levels of laccase activity reported by Hofrichter et al. (1999) and Dinis et al. (2009). Considering this result, it is interesting to note that wheat straw contains high levels of manganese (50 ppm) followed by calcium, potassium, and magnesium among the most abundant metals (Hofrichter et al., 1999).

Regarding the determination of lignin peroxidase activity, the fungus I. lacteus has a maximum activity after 23 days with a value of $0.06 \mathrm{U} \mathrm{ml}^{-1}$ (Fig. 1C) that decreases until day 35. However, this activity increases again at the end of incubation. Euc-1 strain, presents a well-defined peak of LiP activity $\left(0.08 \mathrm{U} \mathrm{ml}^{-1}\right)$ after 35 days of incubation. The low LiP activity level detected can be related to the conditions of culture medium since its production is strongly influenced by the C/N ratio (Tien and Kirk, 1988). In the case of $I$. lacteus, LiP activity fluctuated over time. This behaviour was also observed by other authors (Hwang and Song, 2000). It might be highlighted that Euc-1 strain clearly showed LiP activity, which contradicts to its absence in liquid cultures previously observed (Dias et al., 2004). Although most WRF secrete at least two ligninolytic enzymes, some of them apparently secrete only one oxidative enzyme. Our results show that I. lacteus is essentially a $\mathrm{MnP}$ and LiP producer, while Euc-1 produces all the three oxidative enzymes in solid state fermentation.

The CMCase activity was detected in both studied fungi (Fig. 2A). For the I. lacteus strain the lowest activity was determined in the first half of incubation period while for the Euc-1 strain the lowest values were observed in the second half of the incubation period.

The kinetics of avicelase activity production revealed that strain I. lacteus systematically presented lowest values (Fig. 2B). In terms of enzyme activity for both fungi, the levels of avicelase are about 10 times lower than those of CMCase. Regarding cellulolytic enzyme activity, a common feature is the presence of higher CMCase in relation to avicelase activity (Tanaka et al., 1999; Valášková and Baldrian, 2006).

In this study, basidiomycetes I. lacteus and Euc-1 showed a peak of xylanase activity $\left(0.08 \mathrm{U} \mathrm{ml}^{-1}\right)$ after 10 days of incubation (Fig. 2C). The production of xylanase by WRF and, in particular, by I. lacteus was well documented (Pothiraj et al., 2006). Despite xylanase and cellulolytic activities found during this study were rather low, the activities of xylanase and CMCase were higher than avicelase in roughly the same order of magnitude. Karunanandaa and Varga (1996) have noted that during colonization with Cyathus stercoreus, hemicellulose was degraded preferentially to cellulose. Similarly, Jalč et al. (1996), in a study involving six fungal species, verified that hemicellulose content was much more reduced than cellulose. These relatively low values of cellulolytic and xylanase activities are fairly sound to overall objectives of this work. In fact, as the utilization of fungal pre-treatment is directed to achieve the maximum of lignin breakdown for the improvement of carbohydrates accessibility, the cellulolytic and xylanase activities are prejudicial for the posterior bioconversion of carbohydrate substrate, especially cellulose.

The fungal strains used in this work also revealed the presence of feruloyl esterase activity (Fig. 2D). The peak activity occurred after 10 days (Euc-1) or after 23 days (I. lacteus). At the end of incubation feruloyl esterase activity was not detected in any fungus. To the best of our knowledge, there are no literature data referring to 

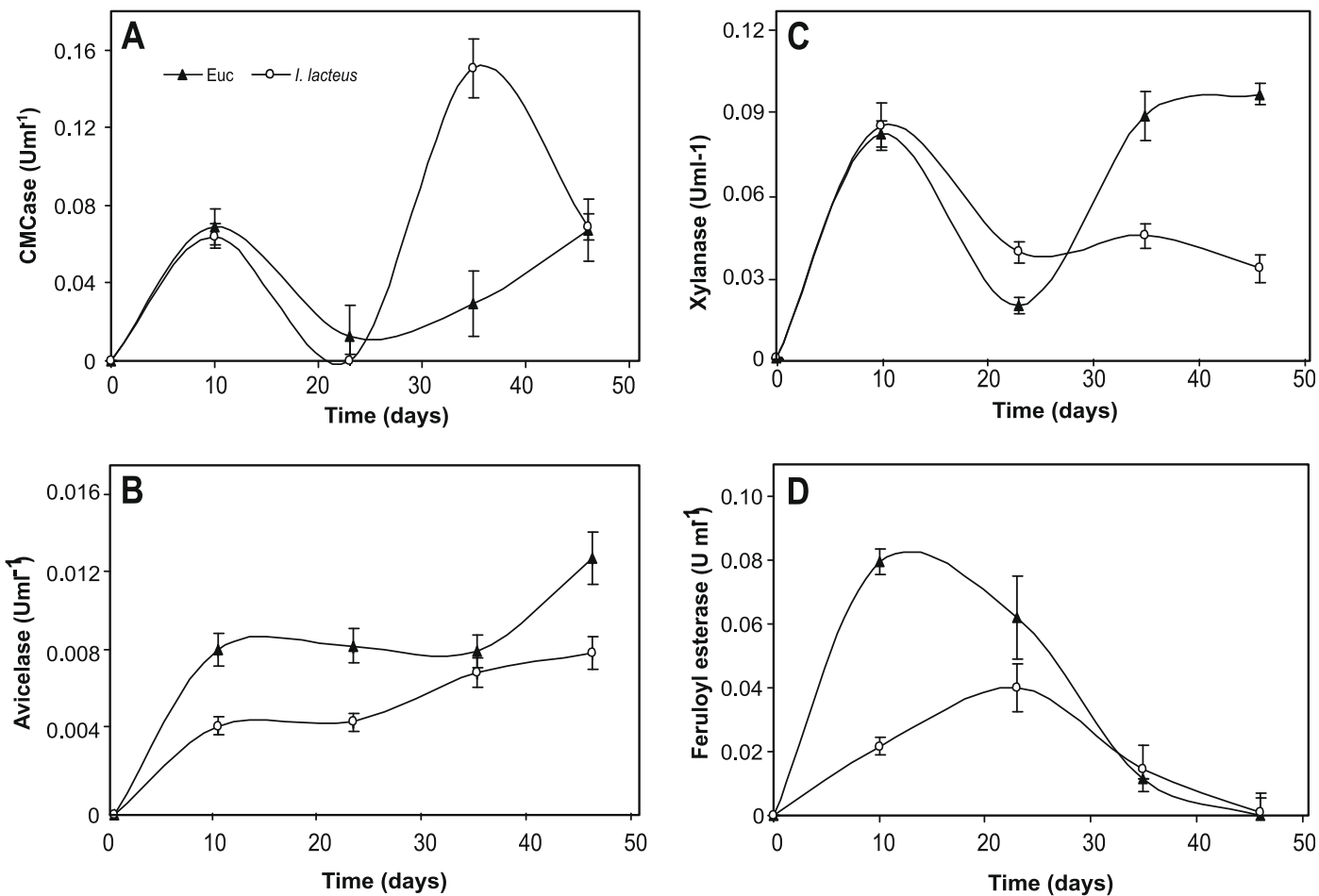

Fig. 2. CMCase (A), avicelase (B) xylanase (C) and feruloyl esterase (D) activities measured during wheat straw solid state fermentation with I. lacteus and strain Euc-1.

the presence of feruloyl esterase activity in the studied fungi, although this enzyme is considered very important in the biodegradation of lignocellulosic materials (Wong, 2005). In monocotyledon plants, ferulic acid is esterified to the C-5 hydroxyl group of arabinopyranose residues of hemicelluloses. Esterified ferulic acid in plant cell wall is a hindrance to biodegradation as it forms bridges between hemicelluloses and lignin, highlighting the importance of feruloyl esterase in the scission of these covalent bonds. As pointed out by Dinis et al. (2009) there is a possible synergy among xylanase and feruloyl esterase to disrupt the hemicellulose-lignin matrix, without mineralization of lignin per se. Therefore, the "bridges" between hemicellulose and lignin might be degraded to promote the efficient lignin removal (Dinis et al., 2009). The fact that feruloyl esterase activity was not detected at the end of incubation period can support its necessity and importance during the initial stage of fungal colonization of wheat straw. This synergistic effect was also underlined by others authors (Wong, 2005). The feruloyl esterase activity may be particularly important for the bio-delignification of wheat straw, which contains a high proportion of ester-linked ferulic and $p$-hydroxycinnamic acid type structures (Sun et al., 1997).

\subsection{Effect of white-rot fungi pre-treatment to substrate saccharification}

The effect of fungal pre-treatment on the cellulose accessibility towards commercial cellulolytic enzyme preparation (Onozuka $\mathrm{R}-10)$ has been evaluated. The significant increased release $(P<$ 0.01 ) of reducing sugars (i.e. substrate saccharification) indicates the improved accessibility of cellulose and xylan after the fungal pre-treatment towards cellulases and xylanases presented in Onozuka R-10 (Fig. 3). Hence, Euc-1 and I. lacteus solid state fermentations favoured the significant increase of cellulose accessibility via breakdown of the lignin-carbohydrate complex. Worth notably, the Euc- 1 and I. lacteus basidiomycetes increased the saccharification about four and three times, respectively. The capacity of white-rot fungi to improve the saccharification of lignocellulosics would be expectable. Indeed, Agosin et al. (1986) reported the increased degradability of cell wall when fungi-treated wheat straw was ruminally fermented in situ. Jung et al. (1992) noted as well an increase on in vitro digestibility in fungi-treated oat straw and Karunanandaa and Varga (1996) found that rice straw digestibility also increased in a 30-day culture with white-rot fungi. More recently, Rodrigues et al. (2008) have also shown that enzyme extracts isolated from solid state fermentation of wheat straw with white-rot fungi can successfully be utilized to enhance the nutritive value of feedstuffs.

Besides the improved accessibility of cellulose towards hydrolytic enzymes after the fungal pre-treatment (due to the partial

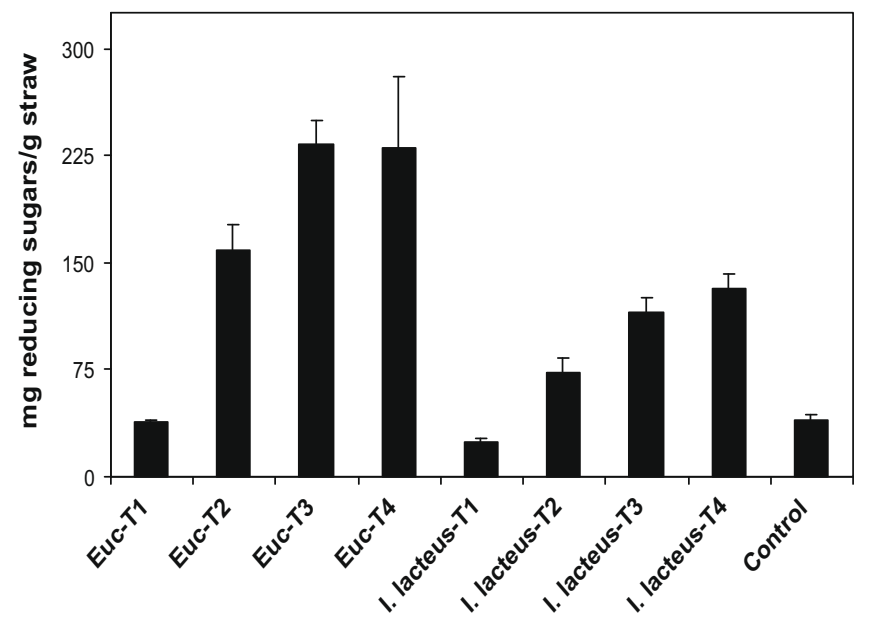

Fig. 3. Enzyme accessibility, expressed as reducing sugars released from pretreated wheat straw after enzymatic hydrolysis (Onozuka R-10) at different fungal pre-treatment periods: T1-10 days; T2-23 days; T3-35 days, T4-46 days and control - abiotic assays. 
delignification), these pronounced saccharification results can be explained by the cellulose conservation during the fungal pretreatment. In fact, low avicelase activity was detected with both fungi and may be responsible for the posterior saccharification results as well.

Thus it may be expected that the carbohydrate/lignin ratio was increased after the fungal pre-treatment of wheat straw allowing the better action of cellulolytic enzymes (Onozuka R-10) in the second step of the process and concomitant promotion of substrate saccharification. The increase of carbohydrate/lignin ratio for Eucalyptus globulus wood degraded by different white-rot fungi was observed previously by del Río et al. (2001).

\subsection{Effect of fungal pre-treatment on cell wall components}

Since fungi revealed an increase of polysaccharide accessibility towards hydrolytic enzymes, a brief study has been carried out to correlate this feature with wheat straw delignification and eventual increase of cellulose/lignin ratio.

The percentage of Klason lignin present in the samples subjected to fungal pre-treatment significantly decreased $(P<0.01)$ from about of $20 \%$ (controls) to about of $13 \%$ after 35 days of incubation (Fig. 4). The potential of white-rot fungi to degrade lignin is well known. In particular, Jalč (2002) reviewed the values of wheat straw lignin degradation with different white-rot fungi that varied between $2 \%$ and $65 \%$. The degree of the delignification determined in this work (about 55\% taking into account the yield of treated matter) is in the same order of magnitude as pointed out by Zhang et al. (2008).

Both fungi promoted similar lignin breakdown from substrate $(P>0.05)$, which reached a maximum between 35 and 46 days of incubation. In the first 10 days of incubation no decrease of lignin was observed (Fig. 4). Similar behaviour has been observed by Arora et al. (2002) and Dinis et al. (2009), who suggested a possible synergistic role among lignolytic enzymes. The sequential production of enzymes may be closely related with this synergism (Zhang et al., 2008).

The percentage of cellulose present in the pre-treated substrate significantly increased $(P<0.05)$ from $50 \%$ to about $70 \%$ after fungal pre-treatment (Fig. 5). This observation is consistent with the levels of lignin obtained and confirmed that the substrate becomes enriched in cellulose. According to our results, wheat straw used in this work presented a ratio cellulose/lignin of 2.7. After pre-treatment (35-46 days) with the basidiomycetes Euc- 1 and I. lacteus, this ratio increased to 5.9 and 4.6 , respectively. These results support the occurrence of lignin breakdown which is in line with the

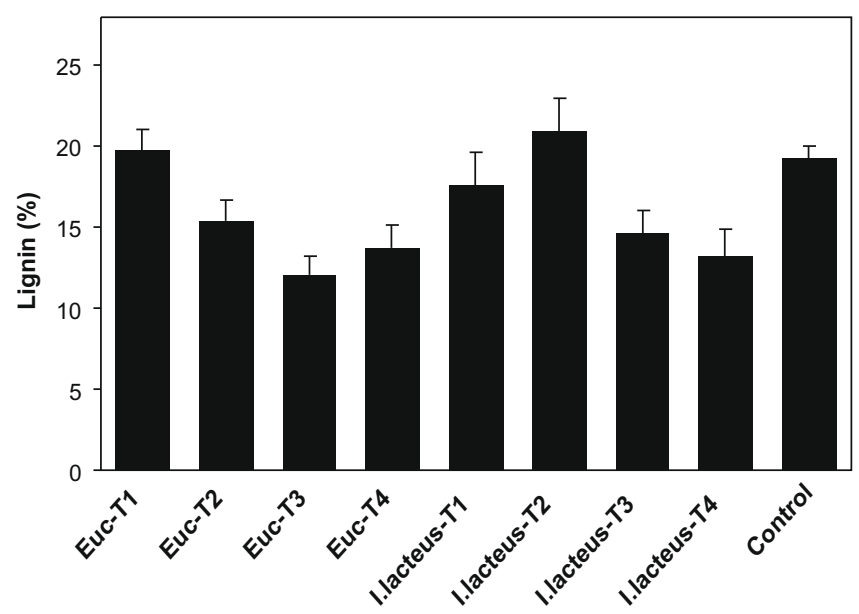

Fig. 4. Percentage of remaining lignin after different fungal pre-treatment periods: T1-10 days; T2-23 days; T3-35 days, T4-46 days and control - abiotic assays.

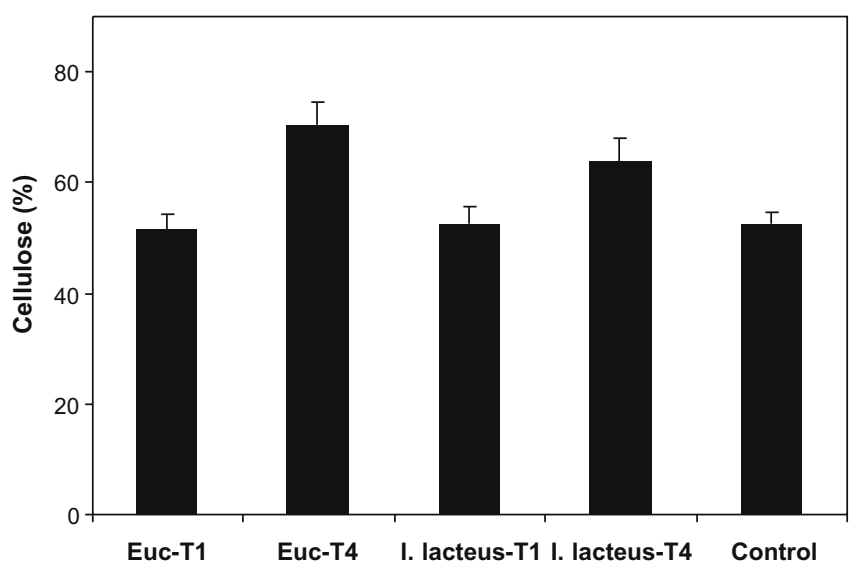

Fig. 5. Percentage of remaining cellulose after different fungal pre-treatment periods: T1-10 days, T4-46 days and control - abiotic assays.

assumption that WRF are the most efficient ligninolytic microorganisms. It is necessary to note that some ligninolytic fungi may show a low increase in the cellulose/lignin ratio due to a simultaneous degradation of carbohydrates (del Río et al., 2001). Hence a selection of fungal species is an important task for the highly selective bio-delignification. The species used in this study presented fairly low cellulase activity that could explain the relatively high selectivity of the delignification.

The I. lacteus strain did not show laccase activity and seems to support the rather common opinion that this enzyme is not essential in lignin biodegradation. Similar suggestions were pointed out with Bjerkandera adusta, another white-rot fungus that did not show laccase activity (Dinis et al., 2009). However, it is known that laccase can play an important role in the lignin degradation with a high content of free phenolic units, such as wheat straw lignin. In particular, Schiesser et al. (1989) reported a direct relationship between the lignin degradation and the laccase production by Pleurotus ostreatus growing on wheat straw. Nevertheless, in the case of the current study the combination of increased laccase and feruloyl esterase activity in the initial stages of biodegradation was a putative factor that could explain the faster bio-delignification of wheat straw promoted by Euc-1 than with I. lacteus.

\section{Conclusions}

The results of this work indicate considerable increase of wheat straw cellulose accessibility (3-4 times) after pre-treatment with basidiomycetes I. lacteus and Euc-1. Both strains revealed low cellulolytic and xylanolytic, but high ligninolytic activities, especially MnP. The high MnP activity seems to be an important pre-requisite for the successful fungal bio-delignification since in the case of I. lacteus, laccase activity was not detected during all pre-treatment period. The initial ratio of cellulose/lignin in the wheat straw of 2.7 was increased to 5.9 and 4.6 after fungal pre-treatment by basidiomycetes Euc-1 and I. lacteus, respectively. Since highly selective delignification of wheat straw was observed, supports the assumption that low-cellulolytic WRF like strain Euc-1 and I. lacteus, could be used to promote lignocellulose bioconversion to value-added products thus contributing to the implementation of an innovative biorefinery concept.

\section{References}

Agosin, E., Tollier, M.T., Brillouet, J.M., Thivend, P., Odier, E., 1986. Fungal pretreatment of wheat straw: effects on biodegradability of cell walls, structural polysaccharides, lignin and phenolic acids by rumen microorganisms. J. Sci. Food Agric. 37, 97-106. 
Arora, D.S., Chander, M., Gill, P.K., 2002. Involvement of lignin peroxidase manganese peroxidase and laccase in degradation and selective ligninolysis of wheat straw. Int. Biodeterior. Biodegrad. 50, 115-120.

Bezerra, R.M.F., Dias, A.A., 2004. Discrimination among eight modified MichaelisMenten kinetics models of cellulose hydrolysis with a large range of substrate enzyme ratios. Inhibition by cellobiose. Appl. Biochem. Biotechnol. 112, 173184.

Browning, B.L., 1967. Methods in Wood Chemistry, vol. 2. Interscience Publications, New York. p. 785 (Chapter 34)

Cardona, C.A., Sanchez, O.J., 2007. Fuel ethanol production: process design trends and integration opportunities. Bioresour. Technol. 98, 2415-2457.

del Río, J.C., Gutiérrez, A., Martínez, M.J., Martínez, A.T., 2001. Py-GC-MS study of Eucalyptus globulus wood treated with different fungi. J. Anal. Appl. Pyrolysis 58-59, 441-452.

Dias, A.A., Bezerra, R.M., Lemos, P.M., Pereira, A.N., 2003. In vivo and laccase catalysed decolourization of xenobiotic azo dyes by a basidiomycetous fungus: characterization of its ligninolytic system. World J. Microbiol. Biotechnol. 19, 969-975.

Dias, A.A., Bezerra, R.M.F., Pereira, A.N., 2004. Activity and elution profile of laccase during biological decolorization and dephenolization of olive mill wastewater. Bioresour. Technol. 92, 7-13.

Dinis, M.J., Bezerra, R.M.F., Nunes, F., Dias, A.A., Guedes, C.V., Ferreira, L.M.M., Cone J.W., Marques, G.S.M., Barros, A.R.N., Rodrigues, M.A.M., 2009. Modifications of wheat straw lignin by solid state fermentation with white-rot fungi. Bioresour Technol. 100, 4829-4835.

Freitas, G.A.S., 2008. Deslenhificação de Materiais Lenhinocelulósicos para Bioconversão. M.Sc. Dissertation, University of Trás-os-Montes e Alto Douro, Vila Real, Portugal.

Gomes, V.A., 2004. Actividade Lenhinocelulolítica de Fungos Basidiomicetas das Regiões norte e centro de Portugal. M.Sc. Dissertation, University of Trás-osMontes e Alto Douro, Vila Real, Portugal.

Heinfling, A., Ruiz-Duenas, F.J., Martínez, M.J., Bergbauer, M., Szewzyk, U., Martínez, A.T., 1998. A study on reducing substrates of manganese-oxidizing peroxidase from Pleurotus eryngii and Bjerkandera adusta. FEBS Lett. 428, 141-146.

Hermoso, J.A. Sanz-Aparicio, J. Molina, R, Juge, N. Gonzalez, R., Faulds, C.B. 2004. The crystal structure of feruloyl esterase A from Aspergillus niger suggests evolutive functional convergence in feruloyl esterase family. J. Mol. Biol. 338 495-506.

Hofrichter, M., Vares, T., Kalsi, M., Galkin, S., Scheibner, K., Fritsche, W., Hatakka, A 1999. Production of manganese peroxidase and organic acids and mineralization of 14C-labelled lignin (14C-DHP) during solid-state fermentation of wheat straw with the white rot fungus Nematoloma frowardii. Appl. Environ. Microbiol. 65, 1864-1870.

Hwang, S.S., Song, H.G., 2000. Biodegradation of pyrene by the white rot fungus, Irpex lacteus. J. Microbiol. Biotechnol. 10, 344-348.

Jalč, D., 2002. Straw enrichment for fodder production by fungi. In: Kempken, F. Bennet, J.W. (Eds.), The Mycota. XI. Agricultural Applications. Springer-Verlag Berlin, Germany, pp. 19-38.

Jalč D., Nerud, F. Erbanová, P. Siroka, P. 1996. Effect of white-rot basidiomycetestreated wheat straw on rumen fermentation in artificial rumen. Reprod. Nutr. Dev. 36, 263-270
Jaszek, M., Zuchowski, J., Dajczak, E., Cimek, K., Graz, M., Grzywnowicz, K., 2006. Ligninolytic enzymes can participate in a multiple response system to oxidative stress in white-rot basidiomycetes: Fomes fomentarius and Tyromyces pubescens. Int. Biodeterior. Biodegrad. 58, 168-175

Jung, H.G., Valdez, F.R., Abad, A.R., Blanchette, R.A., Hatfield, R.D., 1992. Effect of white rot basidiomycetes on chemical composition and in vitro digestibility of oat straw and alfalfa stems. J. Anim. Sci. 70, 1928-1935.

Kalia, V.C., Purohit, H.J., 2008. Microbial diversity and genomics in aid of bioenergy J. Ind. Microbiol. Biotechnol. 35, 403-419.

Karunanandaa, K., Varga, G.A., 1996. Colonization of crop residues by white-rot fungi (Cyathus stercoreus): effect on ruminal fermentation pattern, nitrogen metabolism, and fiber utilization during continuous culture. Anim. Feed Sci. Technol. 61, 1-16.

Levin, L., Herrmann, C., Papinutti, L., 2008. Optimization of lignocellulolytic enzyme production by the white-rot fungus Trametes trogii in solid-state fermentation using response surface methodology. Biochem. Eng. J. 39, 207-214.

Mastihuba, V., Kremnický, L., Mastihubová, M., Willett, J.L., Coté, G.L., 2002. A spectrophotometric assay for feruloyl esterases. Anal. Biochem. 309, 96101.

Novotny, C., Erbanova, P., Cajthaml, T., Rothschild, N., Dosoretz, C., Sasek, V., 2000 Irpex lacteus, a white rot fungus applicable to water and soil bioremediation. Appl. Microbiol. Biotechnol. 54, 850-853.

Pothiraj, C., Kanmani, P., Balaji, P., 2006. Bioconversion of lignocellulose materials Mycobiology 34, 159-165.

Rodrigues, M.A.M., Pinto, P., Bezerra, R.M.F., Dias, A.A., Guedes, C.V.M., Cardoso, V.M.G. Cone, JW. Ferreira, L.M.M. Colaço, J. Sequeira, C.A. 2008. Effect of enzyme extracts isolated from white-rot fungi on chemical composition and in vitro digestibility of wheat straw. Anim. Feed Sci. Technol. 141, 326-338.

Schiesser, A., Filippi, C., Totani, G., Lepidi, A.A., 1989. Fine structure and mechanica properties of straw filaments invaded by Pleurotus ostreatus. Biol. Wastes 27, $87-100$

Sun, R., Lawther, J.M., Banks, W.B., 1997. A tentative chemical structure of wheat straw lignin. Ind. Crop Prod. 6, 1-8.

Tabka, M.G., Herpoel-Gimbert, I., Monod, F., Asther, M., Sigoillot, J.C., 2006. Enzymatic saccharification of wheat straw for bioethanol production by combined cellulase xylanase and feruloyl esterase treatment. Enzyme Microb. Technol. 39, 897-902.

Tanaka, H., Itakura, S., Enoki, A., 1999. Hydroxyl radical generation and phenol oxidase activity in wood degradation by the white-rot basidiomycete Irpex lacteus. Mater. Organismen 33, 91-105.

Tien, M., Kirk, T.K., 1988. Lignin peroxidase of Phanerochaete chrysosporium Methods Enzymol. 161, 238-249.

Valášková, V., Baldrian, P., 2006. Degradation of cellulose and hemicelluloses by the brown rot fungus Piptoporus betulinus production, of extracellula enzymes and characterization of the major cellulases. Microbiology 152 , 3613-3622.

Wong, D.W.S., 2005. Feruloyl esterase, a key enzyme in biomass degradation. Appl. Biochem. Biotechnol. 133, 87-112.

Zhang L, Li, D. Wang, L., Wang, T., Zhang L, Chen, X.D, Mao, Z, 2008. Effect of steam explosion on biodegradation of lignin in wheat straw. Bioresour. Technol. 99, 8512-8515 